\title{
ANALISIS FAKTOR-FAKTOR YANG MEMPENGARUHI KEPATUHAN WAJIB PAJAK ORANG PRIBADI DAN DAMPAKNYA TERHADAP PENERIMAAN PAJAK, DENGAN PELAYANAN FISCUS SEBAGAI VARIABEL MODERATING
}

\author{
JARNO \\ Universitas Pamulang \\ dosen02077@unpam.ac.id
}

\begin{abstract}
The aim of this research is to analyze and ine out the factors that influence the compliance of Individual Taxpayers and their impact on tax revenue, with fiscus service as a moderating variable. The data used are primary data with a total sample of 195 respondents.The analysis used with the Stucture Equations Model (SEM) with the LISREL 8.8 program. The test results show that knowledge of tax has a significant effect on tax compliance. Income level has a significant effect on tax compliance. Fiscus service does not significant effect on tax compliance. Tax Compliance has a significant effect novion tax revenue. Simultaneously Knowledge of taxes, income levels and fiscus services have a significant effect on tax compliance. Simultaneously tax knowledge, income level and tax compliance have a significant effect on tax revenue. iscus service can moderate between tax knowledge and tax compliance. Fiscus service can moderate between income levels and tax compliance.
\end{abstract}

Keywords: Knowledge of Taxes, Income Levels, Fiscus Services, Tax Compliance, Tax Revenue.

\begin{abstract}
Abstrak
Penelitian ini bertujuan untuk mengetahui dan menganalisis faktor-faktor yang mempengaruhi kepatuhan Wajib Pajak Orang Pribadi dan dampaknya terhadap penerimaan pajak, dengan pelayanan fiscus sebagai variabel moderating. Data yang digunakan adalah data primer dengan Jumlah Sampel 195 responden. Analisis yang digunakan dengan Stucture Equations Model (SEM) dengan program LISREL 8.8. Hasil pengujian menunjukkan bahwa Pengetahuan pajak berpengaruh signifikan terhadap kepatuhan pajak, tingkat penghasilan berpengaruh signifikan terhadap kepatuhan pajak, Pelayanan fiscus tidak
\end{abstract}


berpengaruh signifikan terhadap kepatuhan pajak. Kepatuhan Pajak berpengaruh signifikan terhadap penerimaan pajak. Pengetahuan pajak tidak berpengaruh signifikan terhadap penerimaan pajak, Tingkat penghasilan tidak berpengaruh signifikan terhadap penerimaan pajak. Secara Simultan Pengetahuan pajak, Tingkat penghasilan dan pelayanan fiscus berpengaruh signifikan terhadap kepatuhan pajak. Secara simultan pengetahuan pajak, Tingkat penghasilan dan kepatuhan pajak berpengaruh signifikan terhadap penerimaan pajak. Pelayanan fiscus dapat memoderasi antara pengetahuan pajak dan kepatuhan pajak. Pelayanan fiscus dapat memoderasi antara tingkat penghasilan dan kepatuhan pajak.

Kata Kunci: Pengetahuan Pajak, Tingkat Penghasilan, Pelayanan Fiscus, Kepatuhan Pajak, Penerimaan Pajak.

\section{PENDAHULUAN}

\subsection{Latar Belakang Masalah}

Setiap Negara dalam menjalankan tujuan Nasional harus memiliki sumber pendapatan yang dapat menunjang tercapaianya tujuan tersebut. Indonesia memiliki tujuan nasional, yaitu mewujudkan masyarakat yang adil dan makmur sebagaimana yang tercantum dalam Pembukaan UUD 1945. Kontribusi kepatuhan pajak terhadap penerimaan negara diharapkan semakin meningkat dari tahun ke tahun, seiring dengan semakin menurunnya peranan minyak dan gas bumi terhadap penerimaan pajak (Munari, 2005:120).

Selama lima tahun terakhir (tahun 2012 s.d. tahun 2017) target penerimaan pajak yang telah diamanahkan dalam APBN dan perubahannya tidak pernah terealisasi sampai dengan $100 \%$ atau bahkan lebih, seperti ditampilkan dalam data berikut:

Tabel 1. Target dan Relisasi Penerimaan Pajak Tahun 2011 s.d. 2016

\begin{tabular}{|c|r|r|r|}
\hline Tahun & \multicolumn{1}{|c|}{ Target } & \multicolumn{1}{c|}{ Realisasi } & \multicolumn{1}{c|}{$\%$} \\
\hline 2011 & $878,7 \mathrm{~T}$ & $872,6 \mathrm{~T}$ & $99,3 \%$ \\
\hline 2012 & $885,02 \mathrm{~T}$ & $835,25 \mathrm{~T}$ & $94,38 \%$ \\
\hline 2013 & $995,2 \mathrm{~T}$ & $923,3 \mathrm{~T}$ & $92,78 \%$ \\
\hline 2014 & $1.072 \mathrm{~T}$ & $981,9 \mathrm{~T}$ & $91,5 \%$ \\
\hline 2015 & $1.294,25 \mathrm{~T}$ & $1.055 \mathrm{~T}$ & $81,5 \%$ \\
\hline 2016 & $1.546,7 \mathrm{~T}$ & $1.105,81 \mathrm{~T}$ & $81,60 \%$ \\
\hline
\end{tabular}

sumber: Data yang telah diolah dari www.bps.go.id 
Kepatuhan membayar pajak di Indonesia hingga saat ini masih rendah walaupun mengalami peningkatan, dibandingkan dengan negara-negara di Asia Tenggara seperti Malaysia dan Thailand. Pengetahuan tentang peraturan perpajakan memiliki peranan penting untuk menumbuhkan perilaku patuh pajak karena bagaimana mungkin Wajib Pajak dapat mematuhi apabila tidak mengetahui bagaimana peraturan perpajakan, Penelitian yang dilakukan oleh Imam Fauzhi Srikandi Kumadji (2015) pengaruh kualitas jasa konsultan pajak dan pengetahuan pajak terhadap kepatuhan Wajib Pajak (studi pada Wajib Pajak pengguna jasa kantor konsultan pajak Doni Budiono), Selain itu, dalam melakukan pembayaran pajak, Wajib Pajak juga harus memperhatikan kondisi keuangan yang dimilikinya. Secara naluriah setiap orang yang memiliki penghasilan akan memprioritaskan untuk kebutuhan pribadi dan keluarga. Jika sudah pada saatnya penghasilan yang diterima telah melebihi penghasilan tidak kena pajak (PTKP), maka Wajib Pajak akan timbul kewajiban untuk membayar.

Berdasarkan data Dirjen Pajak, jumlah kantor pajak di Indonesia berjumlah yaitu KPP Wajib Pajak besar sebanyak 4 unit, KPP Madya 19 unit, dan KPP Pratama sebanyak 309 unit. Selanjutnya Data Jumlah KPP yang ada di Jakarta sebanyak 70 Kantor Pelayanan Pajak adalah sebagai berikut:

Tabel 2. Data Kantor Pelayanan Pajak Wilayah DKI Jakarta

\begin{tabular}{|c|l|c|}
\hline N0 & \multicolumn{1}{|c|}{ Nama KPP } & Jumlah KPP \\
\hline 1 & Kanwil DJP Wajib Pajak Besar & 3 \\
\hline 2 & Kanwil DJP Jakarta Khusus & 9 \\
\hline 3 & Kanwil DJP Jakarta Pusat & 16 \\
\hline 4 & Kanwil DJP Jakarta Barat & 11 \\
\hline 5 & Kanwil DJP Jakarta Selatan & 13 \\
\hline 6 & Kanwil DJP Jakarta Timur & 9 \\
\hline 7 & Kanwil DJP Jakarta Utara & 9 \\
\hline
\end{tabular}

Sumber: www. Pajak.go.id diakses 16 Mei 2016

\subsection{Perumusan Masalah}

1. Apakah pengetahuan pajak, tingkat penghasilan dan pelayanan fiscus secara parsial dan simultan berpengaruh terhadap kepatuhan Wajib Pajak Orang Pribadi.

2. Apakah pengetahuan pajak, tingkat penghasilan dan kepatuhan pajaksecara parsial dan simultan berpengaruh terhadap penerimaan pajakWajib Pajak Orang Pribadi.

3. Apakah pengetahuan Wajib Pajak berpengaruh terhadap penerimaan pajak yang dimediasi oleh kepatuhan Wajib Pajak.

4. Apakah tingkat penghasilan dapat berpengaruh terhadap penerimaan pajak yang dimediasi oleh kepatuhan Wajib Pajak. 
5. Apakah pelayanan fiscus memoderasi hubungan pengetahuan pajak dengan kepatuhan Wajib Pajak Orang Pribadi.

6. Apakah pelayanan fiscus memoderasi hubungan tingkat penghasilan dengan kepatuhan Wajib Pajak Orang Pribadi.

\subsection{Tujuan Penelitian}

Tujuan penelitian ini adalah sebagai berikut:

1. Untuk menganalisis pengaruh pengetahuan pajak, tingkat penghasilan dan pelayanan fiscus secara parsial dan simultan terhadap kepatuhan Wajib Pajak Orang Pribadi.

2. Untuk menganalisis pengaruh pengetahuan pajak, tingkat penghasilan dan kepatuhan pajaksecara parsial dan simultan terhadap penerimaan pajak Wajib Pajak Orang Pribadi.

3. Untuk menganalisis pengaruh pengetahuan Wajib Pajakterhadappenerimaan pajak yang dimediasi oleh kepatuhan Wajib Pajak Orang Pribadi.

4. Untuk menganalisis pengaruh tingkat penghasilan terhadap penerimaan pajak yang dimediasi oleh kepatuhan Wajib Pajak Orang Pribadi.

5. Untuk menganalisis pengaruh pelayanan fiscus dalam memoderasi hubungan pengetahuan pajak dengan kepatuhan Wajib Pajak Orang Pribadi.

6. Untuk menganalisis pengaruh pelayanan fiscus dalam memoderasi hubungan tingkat penghasilan dengan kepatuhan Wajib Pajak Orang Pribadi.

\subsection{Kontribusi Penelitian}

Kontribus penelitian ini adalah dapat memberikan manfaat secara akademis sebagai berikut:

1. Bagi Peneliti

Untuk menambah pengetahuan, juga memperoleh gambaran langsung bagaimana tentang Wajib Pajak Orang Pribadi dalam hal kepatuhannnya terhadap perpajakan yang dilihat dari sisi pemahaman, tingkat penghasilan dan pelayanan Fiscus dan dampaknya terhadap penerimaan pajak.

2. Bagi Masyarakat

Memberikan pandangan dan masukan bagi masyarakat khususnya bagi Wajib Pajak Orang Pribadi mengenai faktor-faktor yang mempengaruhi kepatuhan Wajib Pajak yang dilihat dari pemahaman, tingkat penghasilan dan pelayanan fiscus dan dampaknya terhadap penerimaan pajak.

3. Bagi Peneliti Lain

Dapat di jadikan sebagai bahan tambahan pertimbangan dan pemikiran dalam penelitian lebih lanjut dalam bidang yang sama yaitu faktor-faktor yang mempengaruhi kepatuhan Wajib Pajak dan dampaknya terhadap penerimaan pajak. 


\section{TINJAUAN TEORI DAN PENGEMBANGAN HIPOTESIS \}

\subsection{Teori Perilaku Terencana (Theory of Planned Behavior)}

Theory of Planned Behavior (TPB) merupakan prediksi perilaku yang baik karena diseimbangkan oleh niat untuk melaksanakan perilaku. Model TPB yang akan digunakan dalam penelitian ini, merupakan pengembangan dari Theory of Reasoned Action dari Ajzen \& Fishbein (1980) dan Fishbein \& Ajzen (1975). Theory of Planned Behavior (TPB) merupakan niat individu untuk melaksanakan perilaku tertentu. Niat diasumsikan untuk menangkap faktor motivasi yang mempengaruhi perilaku, yang mengindikasikan seberapa kuat keinginan orang untuk mencoba, atau seberapa besar usaha yang dilakukan dalam rangka melaksanakan suatu perilaku. Pada umumnya semakin kuat niat untuk melakukan sesuatu, maka semakin memungkinkan untuk pencapaian perilaku (Ajzen, 1991).

Relevansi teori perilaku terencana dengan penelitian ini adalah bahwa dalam teori perilaku terencana (Theory of Planned Behavior) seseorang akan melakukan sesuatu atas dasar faktor motivasi dari seseorang yang melakukan sesuatu, faktor sosial berupa norma atau aturan yang merupakan tekanan yang harus ditaati. Dengan demikian Seseorang atau wajib pajak juga akan berperilaku berdasarkan hal tersebut untuk patuh terhadap perpajakan dan selalu berhubungan dengan niat setiap wajib pajak. Dalam hal ini seseorang akan berperilaku patuh terhadap pajak dapat dilihat dari pengetahuan Wajib pajak tentang pajak, Tingkat penghasilan Wajib Pajak dan Pelayanan Fiscus. Dampak Kepatuhan Pajak secara linier seharnynya meningkatkan penerimaan Negara.

\subsection{Model Kerangka Pemikiran}

Untuk menguji pengaruh variable pengeahuan pajak, tingkat penghasilan dan pelayanan fiscus terhadap kepatuhan pajak dan dampaknya terhadap penerimaan pajak disajikan model kerangka pemikiran sebagai berikut:

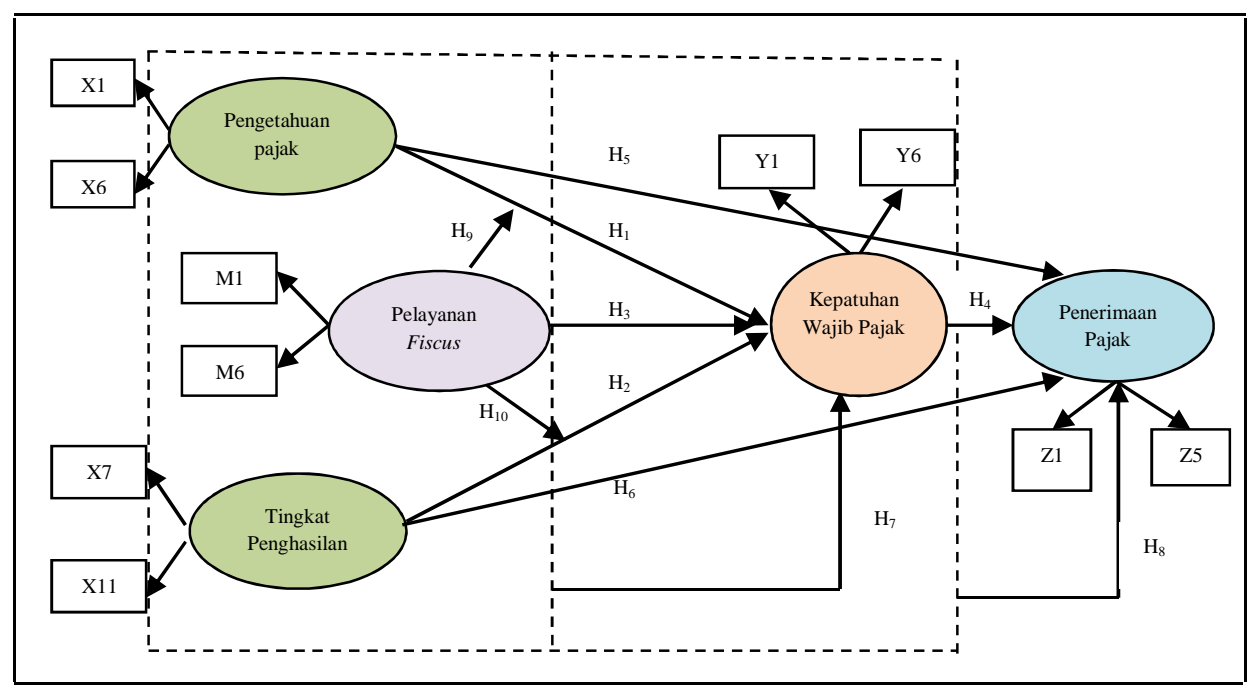

Sumber: Data diolah peneliti

Gambar 1. Model Kerangka Penelitian 


\subsection{Perumusan Hipotesis Penelitian}

Berdasarkan konsep kerangka pemikiran dan model kerangka pemikiran yang disajikan sebelumnaya, maka perumusan hipotesis penelitian adalah sebagai berikut:

$\mathrm{Ha}_{1}$ : Pengetahuan Pajak berpengaruh signifikan terhadap kepatuhan Wajib Pajak Orang Pribadi dalam membayar pajak.

$\mathrm{Ha}_{2}$ : Tingkat Penghasilan Wajib Pajak berpengaruh terhadap kepatuhan Wajib Pajak Orang Pribadi dalam membayar pajak.

$\mathrm{Ha}_{3}$ : Pelayanan fiscus berpengaruh terhadap kepatuhan Wajib Pajak Orang Pribadi.

$\mathrm{Ha}_{4}$ : Kepatuhan pajak berpengaruh terhadap penerimaan pajak orang pribadi.

$\mathrm{Ha}_{5}$ : Pengetahuan Pajak berpengaruh terhadap penerimaan pajak pajak dengan variabel kepatuhan pajak sebagai variabel intervening.

$\mathrm{Ha}_{6}$ : Tingkat Penghasilan Wajib Pajak berpengaruh terhadap penerimaan pajak pajak dengan variabel kepatuhan pajak sebagai variabel intervening.

$\mathrm{Ha}_{7}$ : Pengetahuan Pajak, Tingkat Penghasilan Wajib Pajak dan Pelayanan Fiscus secara simultan tidak berpengaruh signifikan terhadap Kepatuhan Pajak.

$\mathrm{Ha}_{8}$ : Pengetahuan Pajak, Tingkat Penghasilan Wajib Pajak dan Kepatuhan Pajak secara simultan berpengaruh signifikan terhadap Penerimaan Pajak.

$\mathrm{Ha}_{9}$ : Pelayanan Fiscus memoderasi Tingkat Penghasilan Wajib Pajak terhadap kepatuhan Wajib Pajak Orang Pribadi dalam membayar pajak.

$\mathrm{Ha}_{10}$ : Pelayanan Fiscus memoderasi Tingkat Penghasilan Wajib Pajak terhadap kepatuhan Wajib Pajak Orang Pribadi dalam membayar pajak

\section{METODE RISET}

\subsection{Rancangan Penelitian}

Desain penelitian yang digunakan dalam penelitian ini bersifat penjelasan (eksplonatory research) yang menjelaskan hubungan kausal antar variabel melalui pengujian hipotesis. Unit analisis pada penelitian ini, para Wajib Pajak yang melakukan pelaporan dan pembayaran pajak diwilyah kantor pelayanan Jakarta Selatan.

\subsection{Populasi dan Sample}

Populasi dalam penelitian ini adalah Wajib Pajak di Kantor Pelayanan Pajak yang berada di wilayah Jakarta Selatan. Dan Sampel diambil peneliti pada 5 KPP yaitu KPP Pratama Setia Budi Tiga, kantor pelayanan pajak (KPP) Pratama Pasar Minggu, KPP Pratama Setia Budi Satu dan KPP Pratama Setia Budi Dua, dan KPP Pancoran. Kuesioner disebarkan sebanyak 230 kuesioner. Teknis 
pengambilan sampel dengan metode convenience sampling, yaitu pengumpulan data atas dasar kemudahan, (Hamid, 2010).

\subsection{Teknik pengumpulan data}

Teknik pengumpulan data yang peneliti lakukan antara lain:

\subsubsection{Riset Kepustakan (Library Research)}

Riset kepustakaan merupakan penelitian yang dilakukan untuk mendapatkan landasan yang kuat, baik berupa rumus-rumus teknis perhitungan maupun teori-teori yang mendukung obyek penelitian. Sumber-sumber riset kepustakaan yang dilakukan yakni berupa buku-buku text book, literatur-literatur, jurnal-jurnal hasil penelitian para akademisi, situs internet serta sumber-sumber lainnya yang relevan dengan obyek permasalahan yang diteliti.

\subsubsection{Riset Lapangan (Field Research)}

Data utama penelitian ini diperoleh melalui penelitian lapangan, peneliti memperoleh data langsung dari pihak pertama (data primer). Pada penelitian ini, yang menjadi subyek penelitian adalah WPOP yang ada di wilayah Kantor Pelayanan Pajak (KPP) Pratama Jakarta Setia Budi Tiga, KPP Pratama Jakarta Pasar Minggu, KPP Pratama Jakarta Setia Budi Satu dan KPP Pratama Jakarta Setia Budi Dua, dan KPP Pratam Jakarta Pancoran. Peneliti memperoleh data dengan mengirimkan kuesioner kepada Wajib Pajak secara langsung. Data primer diperoleh dengan menggunakan daftar pertanyaan yang telah terstruktur dengan tujuan untuk mengumpulkan informasi dari Wajib Pajak. Sumber data dalam penelitian ini adalah skor masing-masing indikator variabel yang diperoleh dari pengisian kuesinor yang telah dibagikan kepada Wajib Pajak tersebut sebagai responden.

\subsection{Operasionalisasi Variabel}

Operasionalisasi variable disajikan pada tabel sebagai berikut:

Tabel Operasionalisasi Variabel Penelitian

\begin{tabular}{|c|c|c|}
\hline $\begin{array}{c}\text { Nama } \\
\text { Variabel }\end{array}$ & Indikator & Skala \\
\hline \multirow{6}{*}{$\begin{array}{l}\text { Pengetahuan Pajak ( } \\
\left.\xi_{1}\right) \\
\text { (Mardiasmo (2009). }\end{array}$} & 1. Pengetahuan KUP & \multirow{6}{*}{$\begin{array}{c}\text { Skala likert } \\
\text { Ordinal- } \\
\text { Interval }\end{array}$} \\
\hline & 2. Sanksi Pajak. & \\
\hline & 3. Pajak bersifat memaksa sehingga & \\
\hline & $\begin{array}{l}\text { 4. Mengetahui fungsi dan manfaat } \\
\text { pajak. }\end{array}$ & \\
\hline & $\begin{array}{l}\text { 5. Menghitung jumlah pajak yang saya } \\
\text { tanggung. }\end{array}$ & \\
\hline & 6. Mengetahui bagaimana cara mengisi & \\
\hline
\end{tabular}




\begin{tabular}{|c|c|c|}
\hline $\begin{array}{l}\text { Nama } \\
\text { Variabel }\end{array}$ & Indikator & Skala \\
\hline & SPT & \\
\hline \multirow{5}{*}{$\begin{array}{l}\text { Tingkat Penghasilan } \\
(\xi 2) \\
\text { Undang-uandang } \\
\text { PPh pasal } 4 \text { ayat (1) }\end{array}$} & 1. Objek Pajak & \multirow{5}{*}{$\begin{array}{l}\text { Skala likert } \\
\text { Ordinal- } \\
\text { interval }\end{array}$} \\
\hline & 2. Jumlah penghsila Wajib Pajak & \\
\hline & 3. Pelaporan Penghasilan & \\
\hline & 4. Pajak terutang & \\
\hline & 5. Penghasilan dibawah PTKP & \\
\hline \multirow{6}{*}{$\begin{array}{l}\text { Pelayanan Fiscus ( } \\
\xi \text { 3) } \\
\text { (Zeithalm, Bitner } \\
\text { Gremler (dalam } \\
\text { Albari, 2009:2)). }\end{array}$} & 1. Sikap Wajib Pajak yang ramah. & \multirow[t]{6}{*}{ Skala likert } \\
\hline & $\begin{array}{l}\text { 2. Cepat tanggap atas keluhan oleh } \\
\text { Wajib Pajak. }\end{array}$ & \\
\hline & $\begin{array}{l}\text { 3. Informasi dan solusi dengan jelas } \\
\text { dan mudah dimengerti oleh Wajib } \\
\text { Pajak. }\end{array}$ & \\
\hline & $\begin{array}{l}\text { 4. Fiscus berkapasitas untuk } \\
\text { mengarahkan Wajib Pajak. }\end{array}$ & \\
\hline & $\begin{array}{l}\text { 5. Fasilitas Call Center atau Kring } \\
\text { Pajak yang efektif. }\end{array}$ & \\
\hline & $\begin{array}{l}\text { 6. Kualitas pelayanan yang } \\
\text { memuaskan. }\end{array}$ & \\
\hline \multirow{6}{*}{$\begin{array}{l}\text { Kepatuhan Wajib } \\
\text { Pajak } \\
\left(\eta_{1}\right) \\
(\text { Siti Kurnia Rahayu } \\
(2010: 138))\end{array}$} & $\begin{array}{l}\text { 1. Perlu menjalankan KUP secara } \\
\text { mendetail }\end{array}$ & \multirow{6}{*}{$\begin{array}{l}\text { Skala likert } \\
\text { Ordinal- } \\
\text { interval }\end{array}$} \\
\hline & $\begin{array}{l}\text { 2. Kepatuhan Wajib Pajak dalam } \\
\text { mendaftarkan diri }\end{array}$ & \\
\hline & 3. Pengisian SPT yang benar. & \\
\hline & $\begin{array}{l}\text { 4. Kepatuhan untuk menyetorkan } \\
\text { kembali Surat Pemberitahuan (SPT) }\end{array}$ & \\
\hline & $\begin{array}{l}\text { 5. Kepatuhan dalam menghitung dan } \\
\text { pembayaran pajak terutang. }\end{array}$ & \\
\hline & $\begin{array}{l}\text { 6. Kepatuhan dalam pembayaran } \\
\text { tunggakan }\end{array}$ & \\
\hline \multirow{5}{*}{$\begin{array}{l}\text { Penerimaan Pajak ( } \\
\left.\eta_{2}\right) \\
\text { John Hutagaol } \\
(2007: 325)\end{array}$} & $\begin{array}{l}\text { 1. Peran pajak penting bagi } \\
\text { kemandirian pembangunan. }\end{array}$ & \multirow{5}{*}{$\begin{array}{l}\text { Skala likert } \\
\text { Ordinal- } \\
\text { Interval }\end{array}$} \\
\hline & $\begin{array}{l}\text { 2. Penerimaan Pajak perlu dikelola } \\
\text { secara baik dan benar }\end{array}$ & \\
\hline & $\begin{array}{l}\text { 3. Pengetahuan meningkatkan } \\
\text { Penerimaan Pajak. }\end{array}$ & \\
\hline & 4. Kontribusi ke kas Negara & \\
\hline & $\begin{array}{l}\text { 5. Sumber utama Penerimaan Pajak } \\
\text { berasal dari sektor Pajak. }\end{array}$ & \\
\hline
\end{tabular}

\subsection{Metode Analisis Data}

Analisis terhadap Model Penelitian akan dilakukan dengan Structure Equation Model (SEM) melalui dua langkah atau two Step approach (Wijanto 
2008) yaitu menggunakan análisis model pengukuran dan análisis model struktural dengan menggunakan bantuan Software LISREL 8.8 dengan model sebagai berikut:.

\subsection{Pembuatan Diagram Jalur}

Konseptualisasi kerangka pemikiran disajikan melalui diagram jalur (path diagram) berikut ini.

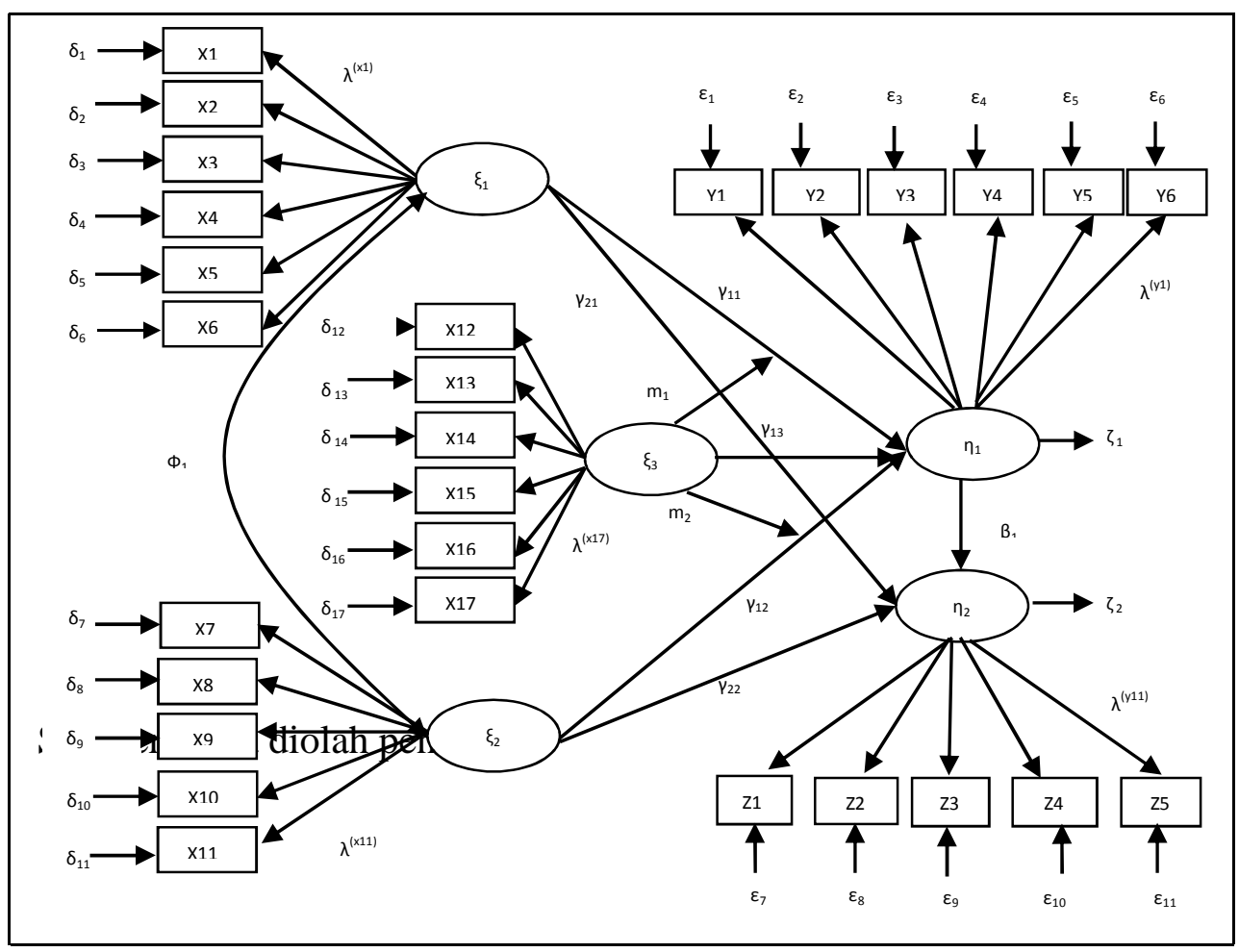

Gambar Diagram Jalur Model Strukural antar Variabel Laten (Structural Model)

Berpegang pada pedoman tersebut maka dalam penelitian ini dapat dikemukakan tiga persamaan umum dalam SEM sebagai berikut:

1. Persamaan Model Pengukuran Variabel Laten Eksogen

Disebut sebagai $X$-Measurement relationship atau $X$-model sebagai $\mathrm{X} p=\lambda_{p m}^{(\mathrm{x})}\left(\xi_{m}\right)+\delta_{p}$, asumsi: $\delta_{p}$ dengan $\xi_{m}$ tidak berkorelasi.

2. Persamaan Model Struktural antar variabel laten. Disebut sebagai Structural Model dan dinyatakan sebagai:

$\eta_{\mathrm{n}}=\gamma_{\mathrm{mm}} \xi_{\mathrm{m}}+\beta_{\mathrm{nn}} \eta_{\mathrm{n}}+\zeta_{\mathrm{n}}$, asumsi: $\zeta_{\mathrm{n}}$ dengan $\xi_{\mathrm{m}}$ dan $\eta_{\mathrm{n}}$ tidak berkorelasi.

Dengan demikian, persamaan struktural antar variabel laten dinyatakan sebagai berikut:

$\eta_{1}=\gamma_{11} \xi_{1}+\gamma_{12} \xi_{2}+\gamma_{13} \xi_{3}+\zeta_{1}$ 


$$
\begin{aligned}
& \eta_{2}=\beta_{1} \eta_{1}+\left(\gamma_{11} \xi_{1} * \gamma_{21} \xi_{1}\right)+\zeta_{2} \\
& \eta_{2}=\beta_{1} \eta_{1}+\left(\gamma_{12} \xi_{1} * \gamma_{22} \xi_{2}\right)+\zeta_{2} \\
& \eta_{1}=\gamma_{11} \xi_{1}+\gamma_{13} \xi_{3}+\left(\gamma_{11} \xi_{1} * \gamma_{13} \xi_{3}\right)+\zeta_{1} \\
& \eta_{1}=\gamma_{12} \xi_{2}+\gamma_{13} \xi_{3}+\left(\gamma_{12} \xi_{2} * \gamma_{13} \xi_{3}\right)+\zeta_{1}
\end{aligned}
$$

Diagram jalur untuk model struktural tersebut tampak pada Gambar sebagai berikut:

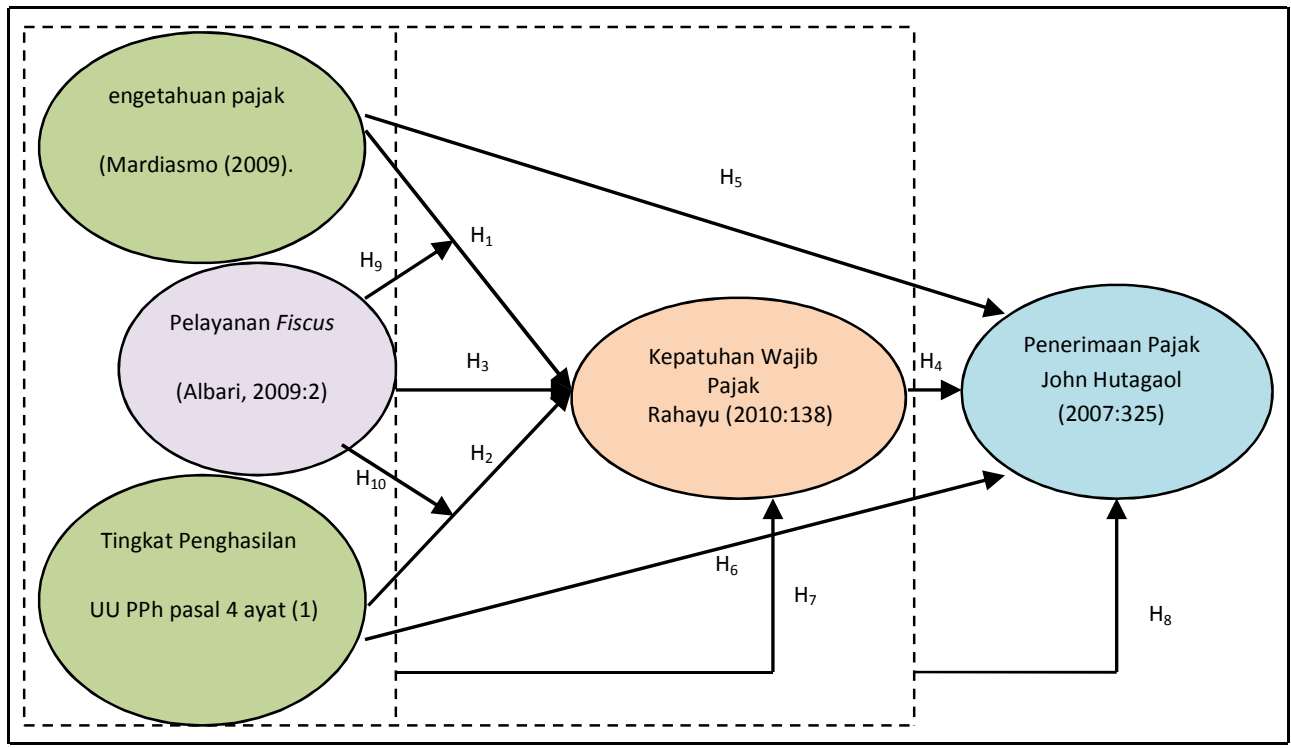

Sumber: Data dikembangkan peneliti

Gambar Diagram Jalur Model Strukural antar Variabel Laten (Structural Model)

\subsection{Penilaian Model Fit}

Dalam penelitian ini, uji kesesuaian model atau model fit menggunakan ukuran uji kesesuaian model (Goodness of Fit Test) versi LISREL (Kusnendi, 2008:26-28).Secara ringkas indeks-indeks yang dapat digunakan untuk menguji kelayakan sebuah model disajikan dalam tabel seabgai berikut:

Tabel 4. Goodness Of index

\begin{tabular}{|l|l|}
\hline Goodness of fit index & Cut of value \\
\hline$x 2$-Chi square & $\begin{array}{l}\text { Diharapkan lebih } \\
\text { kecil }\end{array}$ \\
\hline Significancy probability & $\geq 0,05$ \\
\hline RMSEA & $\leq 0,08$ \\
\hline GFI & $\geq 0,90$ \\
\hline
\end{tabular}

Sumber: (Kusnendi, 2008:26-28). 


\subsection{Dasar Pengambilan Keputusan}

Dalam menentukan pengaruh variable eksogen terhadap variable endogen secara parsial, maka dasar pengambilan keputusan yang digunakan adalah (Sarjono, 2013: 133):

$\mathrm{H} 0=$ Variabel Eksogen tidak berpengaruh terhadap variable endogen

$\mathrm{Ha}=$ Variabel Eksogen berpengaruh terhadap variable endogen.

Dengan nilai kriteria perbandingan $t_{\text {hitung }}$ dan $t_{\text {tabel }}$ sebagai berikut:

1) Jika $t_{\text {hitung }}<t_{\text {tabel }}: \mathrm{H} 0$ diterima (Ha ditolak)

2) Jika $t_{\text {hitung }}>t_{\text {tabel }}: \mathrm{H} 0$ ditolak (Ha diterima)

Selanjutnya untuk menentukan pengaruh variable eksogen terhadap variable endogen secara simultan adalah:

1) Jika $\mathrm{F}_{\text {hitung }}<\mathrm{F}_{\text {tabel }}: \mathrm{H} 0$ diterima (Ha ditolak)

2) Jika $F_{\text {hitung }}>F_{\text {tabel }}: \mathrm{H} 0$ ditolak (Ha diterima)

\section{ANALISIS DATA DAN PEMBAHASAN}

\subsection{Gambaran Umum Objek Penelitian}

Penelitian ini mengambil sampel beberapa Kantor Pelayanan Pajak yang berada di wilayah Jakarta Selatan. Adapun Kantor Pelayanan Pajak dan jumlah kuesioner yang didistribusikan kepada responden distrbusi pengembalian kuesioner sebanyak 85\% atau 195 kuesioner dari 230 kuesioner yang disebarkan. Dengan demikian kuesioner yang masuk dan memenuhi kriteria pengolahan akan diolah dengan program Lisrel dan SPSS untuk memenuhi pengujian dan analisis data.

\subsection{Hasil Uji Kualitas Data}

\subsubsection{Hasil Uji Validitas}

Uji Validitas digunakan untuk menguji sah atau tidaknya suatu kuesioner. Dasar pengambilan keputusan adalah jika nilai $r$ hitung $>r$ table dan bernilai positif maka kuesioner tersebut dinyatakan valid (GHozali, 2011;45). Kuesioner disebar sebanyak 90 kusioner, maka penentuan nilai $r$ tabel adalah $\mathrm{df}=\mathrm{n}-2$ yaitu $195-2=193$. Untuk itu nilai $r$ tabel adalah 0,1406.

Berikut ini disajikan hasil uji validitas untuk variabel pengetahuan pajak, tingkat penghasilan, pelayanan fiscus, kepatuhan pajak dan penerimaan pajak.

\section{Tabel Hasil Uji Validitas Indikator Variabel Penelitian}

\begin{tabular}{|c|c|c|c|}
\hline & Nilai kritis & (r hitung) & Ket. \\
\hline X1 & 0,1406 & 0.686 & Valid \\
\hline X2 & 0,1406 & 0.706 & Valid \\
\hline X3 & 0,1406 & 0.728 & Valid \\
\hline
\end{tabular}




\begin{tabular}{|c|c|c|c|}
\hline & Nilai kritis & (r hitung) & Ket. \\
\hline X4 & 0,1406 & 0.799 & Valid \\
\hline X5 & 0,1406 & 0.666 & Valid \\
\hline X6 & 0,1406 & 0.691 & Valid \\
\hline X7 & 0,1406 & 0.644 & Valid \\
\hline X8 & 0,1406 & 0.727 & Valid \\
\hline X9 & 0,1406 & 0.658 & Valid \\
\hline X10 & 0,1406 & 0.715 & Valid \\
\hline X11 & 0,1406 & 0.660 & Valid \\
\hline M1 & 0,1406 & 0.567 & Valid \\
\hline M2 & 0,1406 & 0.692 & Valid \\
\hline M3 & 0,1406 & 0.708 & Valid \\
\hline M4 & 0,1406 & 0.612 & Valid \\
\hline M5 & 0,1406 & 0.645 & Valid \\
\hline M6 & 0,1406 & 0.595 & Valid \\
\hline Y1 & 0,1406 & 0.610 & Valid \\
\hline Y2 & 0,1406 & 0.623 & Valid \\
\hline Y3 & 0,1406 & 0.665 & Valid \\
\hline Y4 & 0,1406 & 0.687 & Valid \\
\hline Y5 & 0,1406 & 0.727 & Valid \\
\hline Y6 & 0,1406 & 0.656 & Valid \\
\hline Z1 & 0,1406 & 0.701 & Valid \\
\hline Z2 & 0,1406 & 0.689 & Valid \\
\hline Z3 & 0,1406 & 0.784 & Valid \\
\hline Z4 & 0,1406 & 0.853 & Valid \\
\hline Z5 & 0,1406 & 0.722 & Valid \\
\hline
\end{tabular}

Sumber: data diolah

Tabel 4 menunjukkan bahwa seluruh indikator pada variabel penelitian memliliki kriteria valid untuk setiap pertanyaan dengan nilai $r$ hitung $>\mathrm{r}$ tabel. Hal ini berarti bahwa semua item pertanyaan yang digunakan dalam variabel penelitian ini mampu untuk mengungkapkan sesuatu yang diukur pada kuesioner tersebut.

\subsubsection{Hasil uji Reliabilitas}

Hasil pengujian reliabilitas variabel terdapat dalam tabel berikut ini.

Tabel Hasil Uji Reliabilitas

\begin{tabular}{|l|c|c|}
\hline \multicolumn{1}{|c|}{ Variabel } & Cronbach's & Keterangan \\
\hline Pengetahuan Pajak & 0.891 & Reliabel \\
\hline Tingkat Penghasilan & 0.862 & Reliabel \\
\hline
\end{tabular}




\begin{tabular}{|l|c|c|}
\hline \multicolumn{1}{|c|}{ Variabel } & Cronbach's & Keterangan \\
\hline Pelayanan Fiscus & 0.852 & Reliabel \\
\hline Kepatuhan Pajak & 0.864 & Reliabel \\
\hline Penerimaan Pajak & 0.896 & Reliabel \\
\hline \\
Sumber: data diolah
\end{tabular}

Dari tabel di atas menunjukkan bahwa nilai cronbach alpha seluruh variable $>0,70$. Hal ini menunjukkan data yang konsisten yang berarti jika dijukan kembali akan diperoleh jawaban yang relatif sama dengan jawaban sebelumya.

\subsection{Hasil Analisis Data}

Untuk mengetahui apakah model yang diperoleh telah tepat dalam menggambarkan hubungan antar variabel atau telah memenuhi ukuran kesesuaian model (Goodness-of-Fit Measures) sehingga dapat dikatakan model yang diperoleh baik dalam Structural Equation Modelling (SEM), Hasil pengujianvdapat dilihat berdasarkan kriteria pada tabel sebagai berikut.

Tabel Hasil Uji Kecocokan Keseluruhan Model

\begin{tabular}{|l|l|c|l|}
\hline \multicolumn{1}{|c|}{ Kriteria } & \multicolumn{1}{|c|}{$\begin{array}{c}\text { Indikator Tingkat } \\
\text { Kecocokan }\end{array}$} & $\begin{array}{c}\text { Hasil } \\
\text { Estimasi } \\
\text { Model }\end{array}$ & $\begin{array}{c}\text { Tingkat } \\
\text { Kecocokan } \\
\text { Model }\end{array}$ \\
\hline RMSEA & RMSEA $<0,08 ; \mathrm{P}>$ & $\begin{array}{c}0.033 / \\
0.100\end{array}$ & Baik (Good fit) \\
\hline GFI & 0.05 & 0.88 & $\begin{array}{l}\text { Cukup Baik } \\
\text { (Marginal fit })\end{array}$ \\
& GFI $>0,90$, good fit; & & \\
\hline
\end{tabular}

Sumber: Data diolah peneliti

Berdasarkan kriteria dan hasil goodfit dalam rangkuman tabel diatas, maka dapat dilihat kesesuaian model dalam analisis SEM yaitu dilihat dari nilai GFI (Goodness of Fit Index) untuk model yang diteliti sebesar 0.88. Hali ini mendekati nilai 0,90 yang berarti marginal fit dan layak untuk di analisis lebih lanjut. Hasil ukuran kesesuaian absolut menunjukkan model yang diperoleh memenuhi kriteria goodness of fit pada ukuran RMSEA yang relatif kecil $(<0,08)$ sehingga dapat dikatakan model empiris yang diperoleh sudah sesuai dengan model teoritis. 


\subsection{Model Pengukuran Variabel Pengetahuan Pajak}

Variabel laten pengetahuan pajak diukur menggunakan enam buah indicator. Pengujian model pengukuran dilakukan dengan memodifikasi model sehingga bobot faktor masing-masing indikator dalam membentuk variabel laten dapat dilihat pada Gambar berikut:

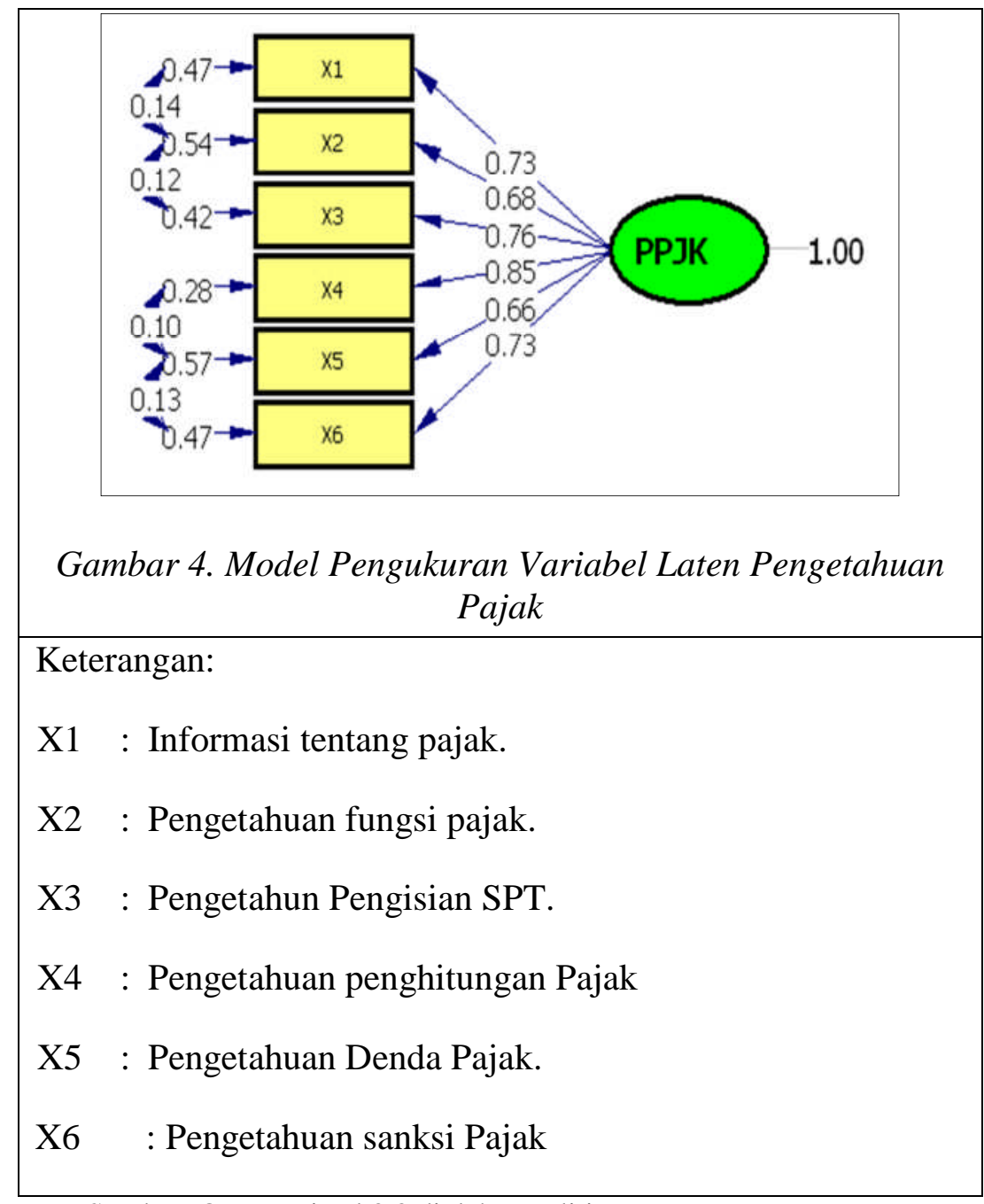

Sumber: Output Lisrel 8,8 diolah peneliti

Pada enam indikator model pengukuran variabel pengetahuan pajak, indikator pengetahuan penghitungan pajak (X4) lebih dominan dalam mengukur pengetahuan pajak. Hal ini tercermin dari bobot faktor sebesar 0.85. Hal ini menunjukkan bahwa pengetahuan pengisian SPT sangat penting bagi wajib pajak.

\subsection{Model Pengukuran Variabel Tingkat Penghasilan}

Variabel laten tingkat penghasilan diukur menggunakan enam buah indikator, bobot faktor masing-masing indikator dalam membentuk variabel laten dapat dilihat pada Gambar sebagai berikut: 


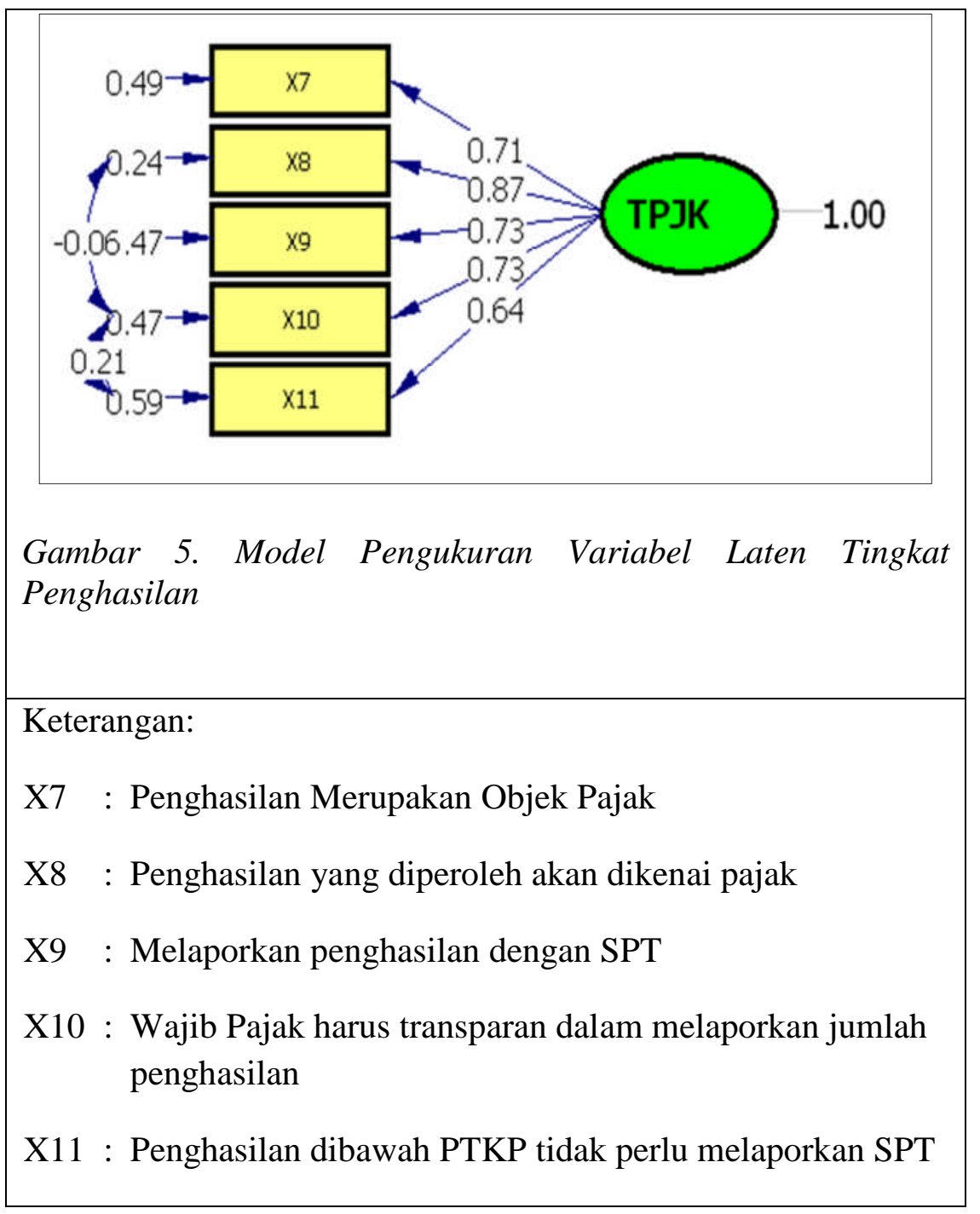

Sumber: Output Lisrel 8,8 diolah peneliti

Berdasarkan gambar 5 diatas, lima indikator model pengukuran variabel tingkat penghasilan, indikator yang memiliki loading factor paling tinggi adalah (X8) setiap penghasilan yang diperoleh akan dikenai pajak sebesar 0,87 lebih dominan dalam mengukur tingkat penghasilan dibanding bobot faktor empat indikator lainnya. Hal ini menunjukkan bahwa penghasilan yang besar akan dikenakan pajak menurut pemahaman Wajib Pajak.

\subsection{Model Pengukuran Variabel Pelayanan Fiscus}

Variabel laten pelayanan fiscus diukur menggunakan enam buah indikator, bobot faktor masing-masing indikator dalam membentuk variabel laten dapat dilihat pada Gambar sebagai berikut: 


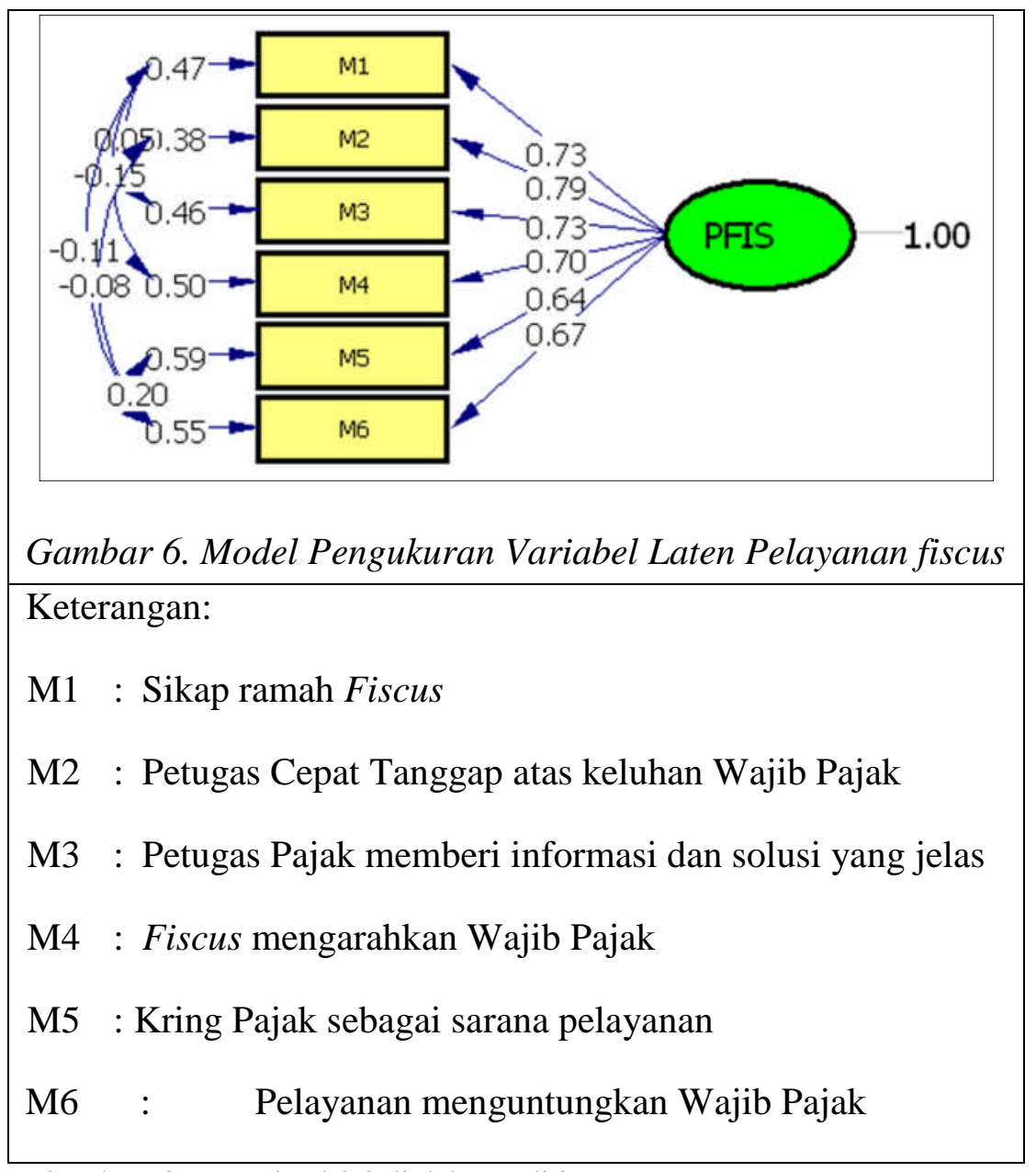

Sumber: Output Lisrel 8,8 diolah peneliti

Pada enam indikator model pengukuran variabel pelayanan fiscus, indikator Petugas pajak cepat tanggap atas keluhan Wajib Pajak (M2) lebih dominan dalam mengukur pelayanan fiscus. Hal ini tercermin dari bobot faktor sebesar 0,79. Petugas Pajak yang tanggap sangat diharapkan oleh wajib pajak.

\subsection{Model Pengukuran Variabel Kepatuhan Pajak}

Variabel laten Kepatuhan Pajak diukur menggunakan enam buah indikator, bobot faktor masing-masing indikator dalam membentuk variabel laten dapat dilihat pada Gambar sebagai berikut: 


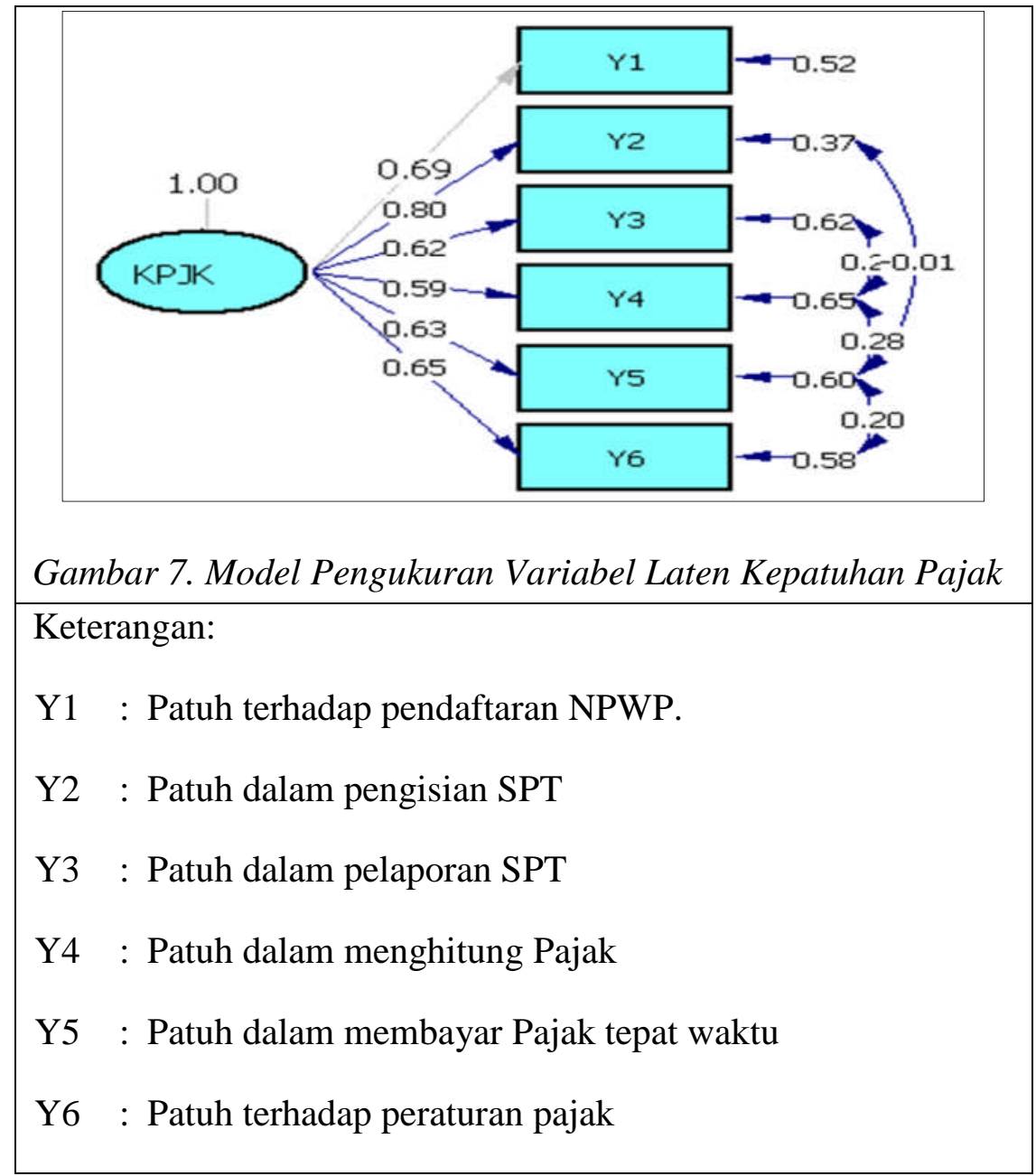

Sumber: Output Lisrel 8,8 diolah peneliti

Pada keenam indikator model pengukuran variabel kepatuhan pajak, indikator yang memiliki loading factor tinggi adalah Patuh terhadap Pengisian SPT (Y2) sebesar 0,80. Hal ini menunjukkan bahwa patuh dalam pengisian SPT sanga membantu untuk peningkaan penerimaan pajak.

\subsection{Model Pengukuran Variabel Penerimaan Pajak}

Variabel laten Penerimaan Pajak diukur menggunakan enam buah indikator, bobot faktor masing-masing indikator dalam membentuk variabel laten dapat dilihat pada Gambar sebagai berikut: 


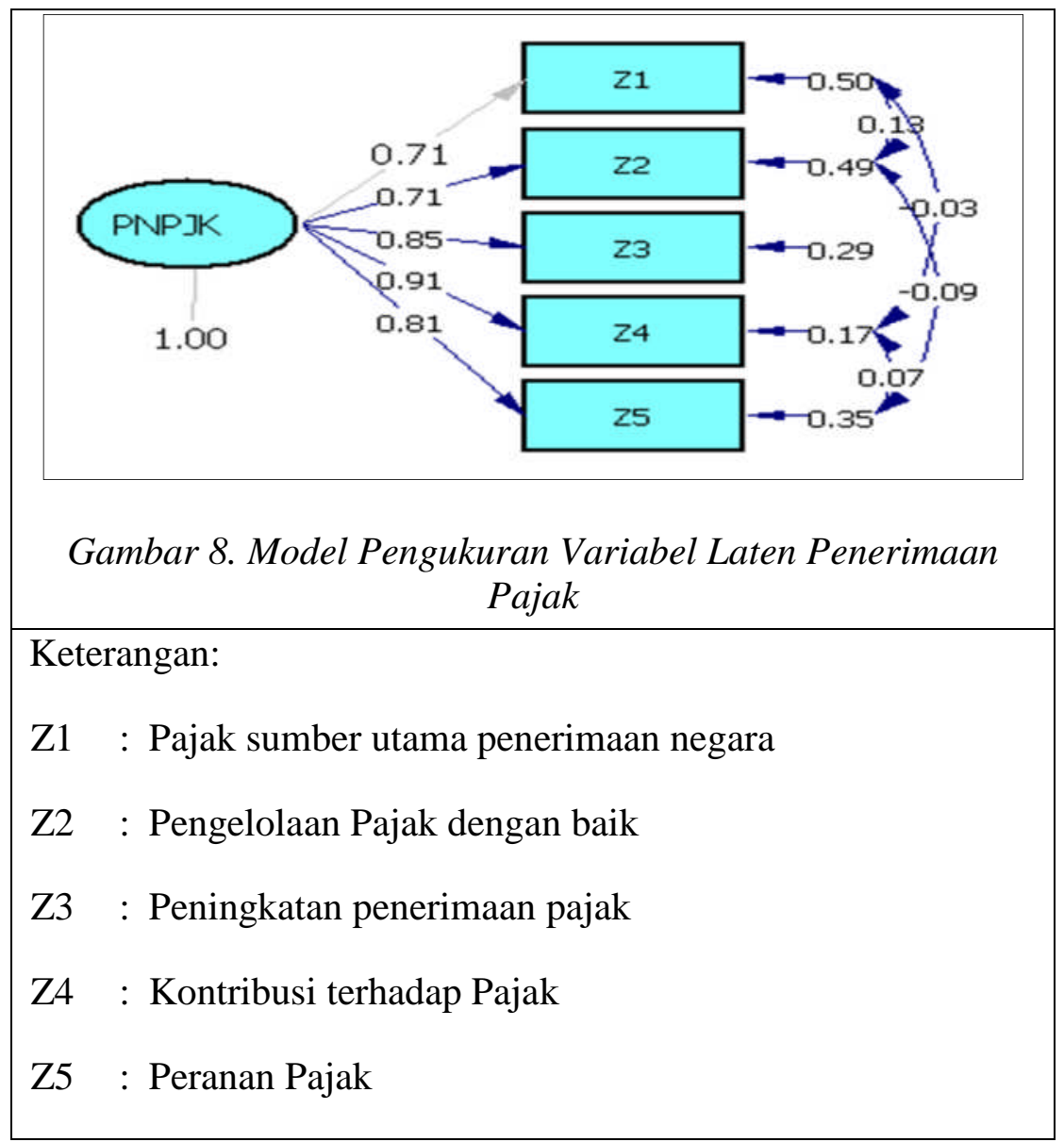

Sumber: Output Lisrel 8,8 diolah peneliti

Pada lima indikator model pengukuran variabel penerimaan pajak, indikator kontribusi pajak (Z4) lebih dominan dalam mengukur penerimaan pajak. Hal ini tercermin dari bobot faktor 0,91. Hal ini menunjukkan bahwa wajib pajak sudah melakukan kontribusi dalam pembayaran pajak.

\subsection{Model Struktural}

Untuk menguji pengaruh dari variable yang akan diuji diuraikan model persamaan structural kelima variabel laten yang sedang diteliti.

Tabel 8. Persamaan struktural antar variabel laten

\begin{tabular}{|c|c|c|c|c|c|}
\hline Konstruk & \multicolumn{4}{|c|}{ Konstruk Eksogen } & \multirow[t]{2}{*}{ Error } \\
\hline & $\xi_{1}$ & $\xi_{2}$ & $\xi_{3}$ & $\eta_{1}$ & \\
\hline$\eta_{1}$ & $\gamma 11 \xi 1$ & $\gamma 12 \xi 2$ & $\gamma 13 \xi 3$ & - & $+\zeta_{1}$ \\
\hline$\eta_{2}$ & $\gamma 21 \xi 1$ & $\gamma 22 \xi 2$ & $\gamma 23 \xi 3$ & $\beta 21 \eta 1$ & $+\zeta_{2}$ \\
\hline
\end{tabular}


Keterangan:

$\xi_{1}=$ Pengetahuan Pajak

$\xi_{2}=$ Tingkat Penghasilan

$\xi_{3}=$ pelayanan fiscus

$\eta_{1}=$ Kepatuhan Pajak

$\eta_{2}=$ Penerimaan Pajak

$\zeta=$ error

$\gamma=$ Koefisien Jalur eksogen terhadap laten endogen

$\beta=$ Koefisien Jalur endogen terhadap laten endogen

Berdasarkan hasil pengolahan dat menggunakan software LISREL 8,8 diperoleh persamaan struktural sebagai berikut:

Tabel 9. Hasil Persamaan Struktural antar variabel laten

\begin{tabular}{|c|c|l|l|c|l|}
\hline $\begin{array}{c}\text { Konstruk } \\
\text { Endogen }\end{array}$ & \multicolumn{4}{|c|}{ Konstruk Eksogen } & \multirow{2}{*}{ Error } \\
\hline$\eta_{1}$ & $\xi_{1}$ & $\xi_{2}$ & $\xi_{3}$ & $\eta_{1}$ & \\
\hline & 0,25 & 0,20 & 0,01 & & + \\
& $(2,15)$ & $(2,34)$ & $(0,08)$ & & 0,87 \\
\hline$\eta_{2}$ & 0,01 & 0,07 & - & 0,79 & $+0,36$ \\
& $(0,23)$ & $(1.16)$ & - & $(7.34)$ & \\
\hline
\end{tabular}

Keterangan: Angka dalam kurung adalah nilai statistik uji-t.

\subsection{Hasil Pengujian Hipotesis}

Dari hasil penggabungan model pengukuran dan model structural diperoleh diagram full model setelah dilakukan modifikasi sebagai berikut.

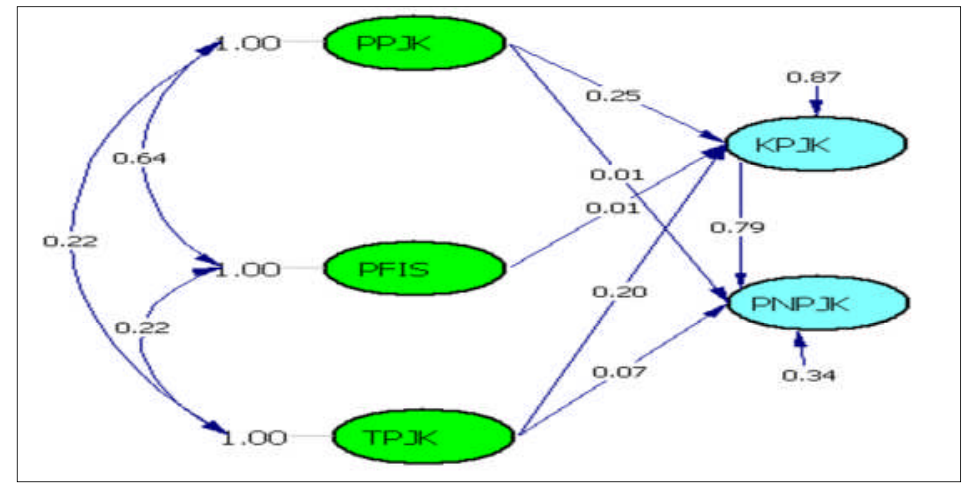

Sumber: Output Lisrel 8,8 diolah peneliti

Gambar 9. Diagram Jalur Model Struktural Antar Variabel Laten

Keterangan:

PPJK = Pengetahuan Pajak

TPJK = Tingkat Penghasilan Wajib Pajak 
PFIS = Pelayanan Fiscus

KPJK = Kepatuhan Pajak

PNPJK = Penerimaan Pajak

\subsection{Pengaruh Pengetahuan Pajak Terhadap Kepatuhan Pajak}

Dari hasil pengujian data, diperoleh hasil seperti yang disajikan dalam Tabel berikut ini.

Tabel Hasil Uji Signifikansi Pengaruh Pengetahuan pajak Terhadap Kepatuhan pajak

\begin{tabular}{|c|c|c|c|}
\hline $\begin{array}{c}\text { Koefisien } \\
\text { Jalur }\end{array}$ & $\mathrm{t}$ - hitung & $\mathrm{t}$ - kritis & Simpulan \\
\hline 0,25 & 2,15 & 1,96 & $\begin{array}{c}\text { Menerima Ha }= \\
\text { Terdapat pengaruh } \\
\text { Signifikan }\end{array}$ \\
\hline
\end{tabular}

Sumber: Output Lisrel 8,8 diolah peneliti

Pada tabel diatas dapat dilihat koefisen jalur pengetahuan pajak terhadap kepatuhan pajak sebesar 0,25 dengan arah positif. Selanjutnya, nilai $t_{\text {-hitung }}$ yang lebih besar dibanding $\mathrm{t}_{\text {kritis }}$ menunjukkan bahwa besarnya pengaruh pengetahuan pajak terhadap kepatuhan pajak sebesar $25 \%$. Hal ini berarti bahwa pengaruh pengetahuan pajak terhadap kepatuhan pajak sangat cukup berarti.

\subsection{Pengaruh Tingkat penghasilan Terhadap Kepatuhan Pajak}

Dari hasil pengujian data, diperoleh hasil seperti yang disajikan dalam tabel berikut ini.

Tabel. Hasil Uji Signifikansi Pengaruh Tingkat penghasilan Terhadap Kepatuhan pajak

\begin{tabular}{|c|c|c|c|}
\hline $\begin{array}{c}\text { Koefisien } \\
\text { Jalur }\end{array}$ & t- hitung & t- kritis & Kesimpulan \\
\hline 0,20 & 2,34 & 1,96 & Menerima Ha= \\
terdapat pengaruh \\
\hline
\end{tabular}

Sumber: Output Lisrel 8,8 diolah peneliti

Pada tabel diatas dapat dilihat koefisen jalur tingkat penghasilan terhadap kepatuhan pajak sebesar 0,20 dengan arah positif. Selanjutnya, nilai $t_{\text {-hitung }}$ yang lebih besar dibanding $t_{\text {kritis }}$ menunjukkan bahwa bahwa besarnya pengaruh tingkat 
penghasilan terhadap kepatuhan pajak sebesar 20\%. Hal ini berarti bahwa pengaruh tingkat penghasilan terhadap kepatuhan pajak cukup berarti.

\subsection{Pengaruh Pelayanan fiscus Terhadap Kepatuhan Pajak}

Dari hasil pengujian data, diperoleh hasil seperti yang disajikan dalam Tabel 8 berikut ini.

Tabel Hasil Uji Signifikansi Pengaruh Pelayanan fiscus Terhadap Kepatuhan pajak

\begin{tabular}{|c|c|c|c|}
\hline $\begin{array}{c}\text { Koefisien } \\
\text { Jalur }\end{array}$ & t-hitung & t-kritis & Kesimpulan \\
\hline 0,01 & 0,08 & 1,96 & $\begin{array}{c}\text { Menolak Ha = Tidak } \\
\text { terdapat pengaruh } \\
\text { signifikan }\end{array}$ \\
\hline
\end{tabular}

Sumber: Output Lisrel 8,8 diolah peneliti

Pada tabel diatas dapat dilihat koefisen jalur pelayanan fiscus terhadap kepatuhan pajak sebesar 0,01 dengan arah positif. Selanjutnya, nilai $t_{\text {-hitung }}$ yang lebih kecil dibanding $t_{\text {kritis }}$ menunjukkan bahwa pelayanan fiscus tidak berpengaruh signifikan terhadap kepatuhan pajak. Hal ini dapat dilihat dari nilai koefisien jalur sebesar 0,01 mengandung makna bahwa besarnya pengaruh pelayanan fiscus terhadap kepatuhan pajak sebesar 1\%. Hal ini berarti bahwa pengaruh pelayanan fiscus terhadap kepatuhan pajak sangat rendah.

\subsection{Pengaruh Kepatuhan Pajak terhadap Penerimaan Pajak}

Dari hasil pengujian data, diperoleh hasil seperti yang disajikan dalam Tabel berikut ini.

Tabel Hasil Uji Signifikansi Pengaruh Kepatuhan Pajak terhadap Penerimaan Pajak

\begin{tabular}{|c|c|c|c|}
\hline $\begin{array}{c}\text { Koefisien } \\
\text { Jalur }\end{array}$ & t-hitung & t-kritis & Kesimpulan \\
\hline 0,79 & 7.34 & 1,96 & $\begin{array}{c}\text { Menerima Ha = terdapat } \\
\text { pengaruh signifikan }\end{array}$ \\
\hline
\end{tabular}

Sumber: Output Lisrel 8,8 diolah peneliti 
Pada tabel diatas dapat dilihat koefisen jalur Kepatuhan pajak terhadap penerimaan Pajak sebesar 0,79 dengan arah positif. Selanjutnya, nilai $t_{\text {-hitung }}$ yang lebih besar dibanding $\mathrm{t}_{\text {rritis }}$ menunjukkan bahwa kepatuhan pajak berpengaruh signifikan terhadap Penerimaan Pajak. Hal ini dapat dilihat dari nilai koefisien jalur sebesar 0.79 mengandung makna bahwa besarnya pengaruh kepatuhan pajak terhadap penerimaan Pajak sebesar 79\%. Hal ini berarti bahwa pengaruh kepatuhan pajak terhadap penerimaan pajak sangat tinggi.

\subsection{Pengaruh Pengetahuan Pajak terhadap Penerimaan Pajak}

Dari hasil pengujian data, diperoleh hasil seperti yang disajikan dalam Tabel berikut ini.

Tabel Hasil Uji Signifikansi Pengaruh Pengetahuan Pajak terhadap Penerimaan Pajak

\begin{tabular}{|l|l|l|c|}
\hline $\begin{array}{c}\text { Koefisien } \\
\text { Jalur }\end{array}$ & t-hitung & t-kritis & Kesimpulan \\
\hline 0,01 & 0,23 & 1,96 & $\begin{array}{c}\text { Menolak Ha = tidak } \\
\text { terdapat pengaruh signifkan }\end{array}$ \\
\hline
\end{tabular}

Sumber: Output Lisrel 8,8 diolah peneliti

Pada tabel diatas dapat dilihat koefisen jalur Pengetahuan pajak terhadap penerimaan Pajak sebesar 0,01 dengan arah positif. Selanjutnya, nilai $t_{\text {-hitung }}$ yang lebih kecil dibanding $t_{\text {kritis }}$ menunjukkan bahwa Penerimaan Pajak tidak berpengaruh signifikan terhadap Penerimaan Pajak. Hal ini dapat dilihat dari nilai koefisien jalur sebesar 0,01 mengandung makna bahwa besarnya pengaruh Pengetahuan pajak terhadap penerimaan Pajak sebesar 1\%. Hal ini berarti bahwa Pengetahuan pajak terhadap penerimaan Pajak sangat rendah.

\subsection{Pengaruh Tingkat penghasilan terhadap penerimaan Pajak}

Dari hasil pengujian data, diperoleh hasil seperti yang disajikan dalam Tabel berikut ini.

Tabel Hasil Uji Signifikansi Pengaruh Tingkat Penghasilan terhadap Penerimaan Pajak

\begin{tabular}{|c|c|c|c|}
\hline $\begin{array}{c}\text { Koefisien } \\
\text { Jalur }\end{array}$ & t-hitung & t-kritis & Kesimpulan \\
\hline 0,08 & 0,72 & 1,96 & $\begin{array}{c}\text { Menolak Ha = Tidak } \\
\text { terdapat pengaruh }\end{array}$ \\
\hline
\end{tabular}




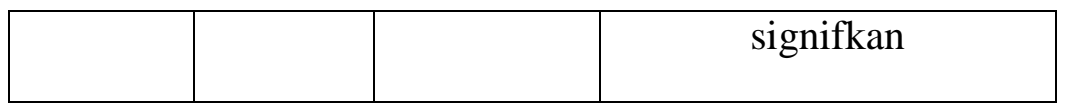

Sumber: Datandiolah peneliti

Pada tabel diatas dapat dilihat koefisen jalur tingkat penghasilan terhadap penerimaan Pajak sebesar 0,07 dengan arah positif. Selanjutnya, nilai $t_{\text {-hitung }}$ yang lebih kecil dibanding $\mathrm{t}_{\text {kritis }}$ menunjukkan bahwa tingkat penghasilan tidak berpengaruh signifikan terhadap Penerimaan Pajak. Hal ini dapat dilihat dari nilai koefisien jalur sebesar 0,08 mengandung makna bahwa besarnya pengaruh Tingkat penghasilan terhadap penerimaan Pajak sebesar 7\%. Hal ini berarti bahwa pengaruh tingkat penghasilan tidak berpengaruh signifikan terhadap penerimaan Pajak atau pengaruh sangat rendah.

\subsection{Pengaruh Pengetahuan Pajak, Tingkat Penghasilan dan Pelayanan Fiscus terhadap Kepatuhan Pajak}

Dari hasil pengujian data, diperoleh hasil seperti yang disajikan dalam Tabel 16 berikut ini.

Tabel Hasil Uji Signifikansi Pengaruh Pengetahuan Pajak, Tingkat penghasilan dan Pelayanan Fiscus terhadap Kepatuhan Pajak

\begin{tabular}{|c|l|l|c|}
\hline $\begin{array}{c}\text { Koefisien } \\
\left(\mathrm{R}^{2}\right)\end{array}$ & F-hitung & F-kritis & Simpulan \\
\hline 0,13 & 5.05 & 2.65 & $\begin{array}{c}\text { Ha diterima = Terdapat } \\
\text { pengaruh signifkan }\end{array}$ \\
\hline
\end{tabular}

Sumber: Datadiolah peneliti

Pada tabel diatas dapat dilihat koefisen Determinasi menunjukkn nilai 0,13 dengan arah positif. Selanjutnya, nilai $\mathrm{F}_{\text {-hitung }}$ yang lebih besar dibanding $\mathrm{F}_{\text {kritis }}$ menunjukkan bahwa pengetahuan pajak, pelayanan fiscus dan tingkat penghasilan berpengaruh signifikan terhadap Kepatuhan pajak. sebesar 13\% sisanya sebesar $87 \%$ dipengaruhi oleh faktor lain diluar penelitian. Hal ini berarti bahwa Secara simultan pengetahuan pajak, tingkat penghasilan dan pelayanan fiscus berpengaruh terhadap kepatuhan pajak.

\subsection{Pengaruh Pengetahuan Pajak, Tingkat penghasilan dan Kepatuhan Pajak terhadap Penerimaan Pajak}

Dari hasil pengujian data, diperoleh hasil seperti yang disajikan dalam tabel berikut ini. 
Tabel Hasil Uji Signifikansi pengaruh Pengetahuan Pajak, Tingkat penghasilan dan Kepatuhan Pajak terhadap Peneriman Pajak

\begin{tabular}{|c|c|c|c|}
\hline $\begin{array}{c}\text { Koefisien } \\
\text { Determinasi }\left(\mathrm{R}^{2}\right)\end{array}$ & F-hitung & F-kritis & Simpulan \\
\hline 0,66 & 4,34 & 2.65 & $\begin{array}{c}\text { Ha diterima = terdapat } \\
\text { pengaruh signifkan }\end{array}$ \\
\hline
\end{tabular}

Sumber: Data diolah peneliti

Pada tabel diatas dapat dilihat koefisen Determinasi menunjukkan nilai 0,66 dengan arah positif. Selanjutnya, nilai $F_{\text {-hitung }}$ yang lebih besar dibanding $\mathrm{F}_{\text {kritis }}$ menunjukkan bahwa pengetahuan pajak. tingkat penghasilan dan kepatuhan pajak berpengaruh signifikan terhadap penerimaan pajak sebesar 66\%. Sisanya sebesar $44 \%$ dipengaruhi oleh faktor lain diluar penelitin. Hal ini berarti bahwa Secara simultan pengetahuan pajak, tingkat penghasilan dan kepatuhan pajak berpengaruh signifikan terhadap penerimaan pajak.

\subsection{Pengaruh Pengetahuan Pajak terhadap kepatuhan pajak yang dimoderasi oleh Pelayanan Fiscus.}

Untuk menguji pengaruh pengetahuan pajak terhadap kepatuhan pajak dengan pelayanan fiscus sebagai variabel moderasi dengan menggunakan bantuan software SPSS 22. Hasil moderasi akan dilihat dari perubahan nilai adjust $r$ square sebelum dan sesudah menambahkan variabel moderating yaitu interaksi antara pengetahuan pajak dan pelayanan fiscus. Dari hasil pengujian data, diperoleh hasil seperti yang disajikan dalam tabel berikut ini.

Tabel Hasil Uji Moderasi Pelayanan fiscus dan pengetahuan pajak

\begin{tabular}{|l|c|c|c|}
\hline Variabel diuji & $\begin{array}{c}\text { Nilai R } \\
\text { (Pertama } \\
\text { ) }\end{array}$ & $\begin{array}{c}\text { Nilai } \mathrm{R}^{2} \\
\text { (Kedua) }\end{array}$ & Keterangan \\
\hline PPJK dan PFIS & 0,056 & - & $\begin{array}{l}\text { Mengalami } \\
\text { peningkatan }\end{array}$ \\
\hline $\begin{array}{l}\text { Mod1 (PPJK } \\
\text { *PFIS) }\end{array}$ & - & 0,080 & $<0,05$ \\
\hline $\begin{array}{l}\text { Nilai } \\
\text { Signifiknsi }\end{array}$ & - & 0,026 & \\
\hline \multicolumn{2}{|l|}{ Dependent Variabel: KPJK } \\
\hline
\end{tabular}

Sumber: Data direkap dari hasil SPSS 22

Pada tabel diatas dapat dilihat bahwa pengujian secara parsial variabel pengetahuan pajak dan pelayanan fiscus tanpa memasukkan variabel moderasi menunjukkan nilai $\mathrm{r}$ square 0.056. selanjutnya setelah diikutsertakan interaksi variabel pengetahuan pajak dan pelayanan fiscus (PPJK*PFIS) maka niai $r$ square 
menjadi 0,080, dengan signifikansi $0,026<0,05$. Artinya semakin tinggi pengetahuan pajak dan pelayanan fiscus akan meningkatkan kepatuhan pajak.

\subsection{Pengaruh Tingkat Penghasilan terhadap kepatuhan pajak yang dimoderasi oleh Pelayanan Fiscus.}

Untuk menguji pengaruh tingkat penghasilan Wajib Pajak terhadap kepatuhan pajak dengan pelayanan fiscus sebagai variabel moderasi dengan menggunakan bantuan software SPSS 22, akan dilihat dari perubahan nilair square sebelum dan sesudah menambahkan variabel moderating yaitu interaksi antara tingkat penghasilan dan pelayanan fiscus. Dari hasil pengujian data, diperoleh hasil seperti yang disajikan dalam tabel berikut ini.

Tabel Hasil Uji Moderasi Pelayanan fiscus dan tingkat penghasilan

\begin{tabular}{|c|c|c|c|}
\hline Variabel diuji & $\begin{array}{l}\text { Nilai } R^{2} \\
\text { (Pertama) }\end{array}$ & $\begin{array}{l}\text { Nilai R }{ }^{2} \\
\text { (Kedua }\end{array}$ & Keterangan \\
\hline TPJK dan PFIS & 0,052 & - & \multirow{2}{*}{$\begin{array}{l}\text { Mengalami } \\
\text { peningkatan }\end{array}$} \\
\hline $\begin{array}{l}\text { Mod1 (TPJK } \\
\text { *PFIS) }\end{array}$ & - & 0,071 & \\
\hline Nilai Sig. & - & 0,050 & $=0,05$ \\
\hline
\end{tabular}

Dependent Variabel: KPJK

Sumber: Data direkap dari hasil SPSS 22

Pada tabel diatas dapat dilihat bahwa pengujian secara parsial variabel tingkat penghasilan dan pelayanan fiscus tanpa memasukkan variabel moderasi menunjukkan nilai $r$ square 0.052. selanjutnya setelah diikutsertakan interaksi variabel tingkat penghasilan dan pelayanan fiscus (TPJK*PFIS) maka niai $r$ square menjadi 0,071 signifikansi $0,05=0,05$. Artinya semakin tinggi tingkat penghasilan dan pelayanan fiscus akan meningkatkan kepatuhan pajak.

\section{KESIMPULAN DAN SARAN}

\subsection{Kesimpulan}

Berdasarkan pada data yang telah dikumpulkan dan pengujian yang telah dilakukan terhadap permasalahan dengan menggunakan model structur equations model (SEM) dan regresi berganda, maka dapat diambil kesimpulan sebagai berikut:

1. Pengetahuan pajak berpengaruh signifikan terhadap kepatuhan pajak..

2. Tingkat penghasilan berpengaruh signifikan terhadap kepatuhan pajak.

3. Pelayanan fiscus tidak berpengaruh signifikan terhadap kepatuhan pajak.

4. Kepatuhan pajak berpengaruh signifikan terhadap penerimaan pajak.

5. Pengetahuan pajak tidak berpengaruh signifikan terhadap penerimaan pajak. 
6. Tingkat penghasilan tidak berpengaruh signifikan terhadap penerimaan pajak.

7. Secara simultan pengetahuan pajak, tingkat penghasilan dan Pelayananfiscus berpengaruh signifikan terhadap kepatuhan pajak

8. Secara simultan pengetahuan pajak, tingkat penghasilan dan kepatuhan pajak berpengaruh signifikan terhadap penerimaan pajak

9. Pelayanan fiscus dapat memoderasi antara pengetahuan pajak dan kepatuhan pajak. Semakin meningkat pelayanan dan pengetahuan pajak makan kepatuhan pajaka akan semakin baik.

10. Pelayanan fiscus dapat memoderasi antara tingkat penghasilan dan kepatuhan pajak. Semakin meningkat pelayanan pajak dan tingkat penghasilan wajib pajak maka kepatuhan akan semakin meningkat.

\subsection{Saran}

\subsubsection{Saran Praktis}

Berdasarkan atas hasil penelitian ini yang menyatakan bahwa pengetahuan pajak, tingkat penghasilan dan pelayanan fiscus memiliki pengaruh signifikan terhadap kepatuhan, dan memiliki dampak terhadap penerimaan pajak. Secara teoritis saran yang perlu dicermati adalah:

1. Perlu adanya peningkatan intensitas pelayanan dan sosialisasi terhadap Wajib Pajak agar Wajib pajak semakin memahami pentingnya pajak bagi negara.

2. Pengetahuan Pajak sangat diperlukan bagi setiap wajib pajak agar dapat menghitung, melapor dan membayar sesuai dengan ketentuan agar penerimaan pajak meningkat.

3. Kepatuhan pajak masih sangat kecil sehingga pemerintah perlu melakukan pendekatan kepada warga masyarakat dan memberikan solusi yang nyaman agar wajib pajak mau mentaatinya.

\subsubsection{Saran Teoritis}

Penelitian ini masih sangat perlu ditingkatkan agar keakurannya teruji lebih komprehensif. Dengan demikian yang perlu penulis sarankan adah:

1. Menambah jumlah responden dan wilayah penelitian dari berbagai KPP yang ada di Indonesia sehingga menambah sebuah penelitian yang lebih baik untuk meyakinkan hasil dari penelitian.

2. Menambahkan jumlah variabel independen yang dapat mempengaruhi penerimaan pajak, seperti kepatuhan Wajib Pajak, penagihan pajak, pemahaman Wajib Pajak, Sanksi pajak.

3. Responden dapat diambil dari sisi fiscus dan Wajib Pajak agar dapat diperbandingkan pendapat dari sisi fiscus dan Wajib Pajak. 
Vol.1, No.3, Sept 2018

\section{DAFTAR PUSTAKA}

Ajzen, Icek. (2002) . Constructing a TPB Questionnaire: Conceptual and Methodological Considerations (Revised January,2006), (Online), (http://people.umass. edu/aizen/pdf/tpb.measurement.pdf, diakses 27 Maret 2016), 2.

(2005). Attitudes, Personality and Behaviour 2nd ed". New York; Open University Press.

Albari. 2009. Pengaruh kualitas Layanan Terhadap Kepatuhan Membayar Pajak. Jurnal Siasat Bisnis, 13 (1) : 1-13

Alabebe o. James at.Al., (2011). Individual tax payers' attitude and compliance behavior in Nigeria: The Moderating role of financial condition andrisk preference, September 2011, Journal of accounting dan taxation Vol. 3 (5), pp. 91 - 104. available online journal at http://www.academicjournals.org/JAT, ISSN 2141-6664@2011 Academic Journals.

Amilin, (2016). Pengaruh konseling, pengawasan, dan pemeriksaan pajak terhadap kepatuhan wajib pajak dalam memenuhi kewajiban perpajakannya dan dampaknya terhadap penerimaan negara. Jakarta; Jurnal Akuntansi/Volume XX, No. 02, Mei 2016: 285-300, Universitas Taruma Negara,

Carolina, Verani dan Timbul H. Simanjuntak, 2010. Pengaruh Tax Knowledge dan Persepsi Tax Fairness terhadap Tax Compliance Wajib Pajak Badan yang terdafar di KPP Madya Bandung. Prosiding Seminar Nasional, Bandung.

Carolina, Verani, Meythi dan Riki Martusa, (2010). Tax Culture: Dasar Pelaksanaan Perpajakan III, Bandung,

Caro, L. M., \& Garcia, J. A. M. (2007). Measuring perceive service quality in urgent transport service. Journal of Retailing and Costumer Service, 14(1), $60-72$.

Chaerunisa, (2010). Analisis Pengaruh Tingkat Penghasilan dan Sanksi Pajak terhadap Kepatuhan Wajib Pajak dalam menyampaikan SPT tahunan uantuk Wajib Pajak orang Pribadi di Wilayah Kembangan, Jakarta Barat, Jakarta ; Journal Accounting, UIN Syarif Hidayatullah.

Cohen Jeffrey, Gil B, Manzon Jr, 2015. Contextual and Individual Dimensions ofTaxpayer Decisin making, Accounting Department, Carrol ScHOol of Management Boston College.

Febria Anggraini P. L., dan waluyo. (2014). Faktor-Faktor yang mempengaruhi kepatuhan Wajib Pajak Orang Pribadi (Studi pada Wajib Pajak Orang 
Pribadi yang terdaftar di KPP Kebayoran Baru Tiga), e-Journal Magister Akuntansi Trisakti, Vol 1, No. 1 Februari 2014 Hal 51-68

Hanjarti Puspa Arum dan Zilaikha (2012). Pengaruh Kesadaran Wajib Pajak pelayanan Fiscus, dan sanksi pajak terhadap kepatuhan Wajib Pajak Orang Pribadi yang melakukan kegiatan usaha dan Pekerjaan Bebas. (Studi di Wilayah KPP Pratama Cilacap), Diponegoro Journal of accounting vol 1, No. 1, tahun 2012 hal 1-8.

Ghozali, Imam, (2011). Aplikasi Analisis Multivariate Dengan Program SPSS, Badan Penerbit Universitas Diponegoro, Semarang

Gardina dan Haryanto. (2006). Pengetahuan Pajak. Jakarta: Raja Grafindo Persada.

Imam Fauzhi, Srikandi Kumadji, (2015). Pengaruh Kualitas Jasa Konsultan Pajak Dan Tingkat penghasilan Terhadap Kepatuhan Wajib Pajak (Studi Pada Wajib Pajak Pengguna Jasa Kantor Konsultan Pajak Doni Budiono) Jurnal Administrasi Bisnis - Perpajakan (Jab)|Vol. 4 No. 1 Maret 2015

Ikhsan Lubis Arfan, (2010). Akuntansi Keprilakuan . Jakarta; Edisi II. Salemba Empat.

Imaniyah, Nur dan Bestari Dwi Handyani. (2008). Pengaruh Penghasilan dan Pengetahuan Perpajakan Terhadap Wajib Pajak dalam Membayar Pajak Bumi dan Bangunan (PBB) di Kelurahan TegalrejoI, Simposium Nasional Akuntansi.

Jogiyanto, (2007). Sistem Informasi Keperilakuan. Edisi Revisi. Yogyakarta: Andi Offset

Kertajaya, Himawan, (2007) Perilaku Sosial Dalam Ekonomi, Aksara, Jakarta,.

Kusnendi. (2008). Model-Model Persamaan Struktural. Satu dan Multigroup Sampel dengan Lisrel. Bandung Albeta.

Mardiasmo, (2009). Perpajakan edisi revisi 2009, Edisi XIV, Yogyakarta, Andi.

Prabowo Yudo Jayanto, (2011). Faktor-Faktor Ketidakpatuhan Wajib Pajak Jdm

Vol. 2, No. 1, , pp: 48-61 Jurnal Dinamika Manajemen http://journal.unnes.ac.id/nju/index.php/jdm

PSAK (2010). Pasal 23 tentang Pengertian Penghasilan, Ikatan Akuntan Indonesia, Jakarta

Resmi, Siti. (2009). Perpajakan : Teori dan Kasus, Jakarta; Buku 1, Edisi 5, Salemba Empat.

Setiaji, Gunawan dan Hidayat Amir.(2005). Evaluasi Kinerja Sistem Perpajakan Indonesia. Jurnal Ekonomi Universitas Esa Unggul. Edisi November 2005.

Siti Kurnia Rahayu, dan Ely Suhayati, (2010). Perpajakan: Teori dan Teknis Perhitungan, Yogyakarta; Graha Ilmu 
Sugiyarti, S. R. (2011). Penilaian Kinerja dalam Upaya Peningkatan Pelayanan Publik.Jurnal Transformasi 14(21): 8-13

Suherman Ade, (2011). Analisis Pengaruh kompetensi Account Representative dan Independensi Account Representative sertapenerapan Benchmarking Laporan Keuangan Wajib Pajak terhadap Penerimaan Pajak Kanwil DJP Sumut I, Tesis, Medan. Universitas Sumatera Utara.

Suhendra, E.S, (2010). Pengaruh Tingkat Kepatuhan Wajib Pajak Badan Terhadap Peningkatan Penerimaan Pajak Penghasilan Badan, Jurnal Ekonomi Bisnis

Supriyatin dan Hidayati, Nur. (2008). Pengaruh Pengetahuan Pajak dan Persepsi Wajib Pajak tehadap Kepatuhan Wajib Pajak. Akuntansi dan Tekhnologi Informasi. Volume 7, No. 1, 41-50.

Undang-Undang Republik Indonesia, (2015). Nomor 27 Tahun 2014 Tentang Anggaran Pendapatan Dan Belanja Negara Tahun Anggaran 2015

Waluyo. (2013) Perpajakan Indonesia, Jakarta; Salemba Empat.

Witono, Banu. (2008). Peranan Pengetahuan Pajak pada Kepatuhan Wajib Pajak dengan persepsi keadilan pajak sebagai variabel intervening. Jurnal akuntansi dan Keuangan. Volume 7, No. 2, 196-208

Wijanto, Setyo Hari. (2008). Structural Equation Modeling dengan LISREL 8.8 Konsep dan Tutorial. Yogyakarta : Graha Ilmu.

Sarjono H. Julianita W. (2013), SPSS vs Lisrel Sebuah Pengantar Aplikasi Untuk Riset, Jakarta; Salemba Empat, Cetakan ke-dua.

http://bisnis.liputan6.com/read/2212865/ "Jumlah Wajib Pajak yang melaporkan spt-pph-2015-naik-17. Diakses 01 April 15

http://www.sinarharapan.co/news/read/151104013/2016-ditetapkan-sebagaitahun penegakan-hukum-pajak, diakses 01 April 15

http://selatan.jakarta.go.id/news/2016/02/1300-usaha-di-jaksel-terkoneksi-sistempajak-online 